\title{
A Case of Solitary Fibrous Tumor in the Nasal Cavity Resected via Endoscopic Surgery
}

\author{
Kayoko Hattori ${ }^{1)}$, Takeshi Morita ${ }^{1)}$, Nobuya Fujiki ${ }^{2}$, \\ Kosaku Yamada ${ }^{1)}$, Takatoshi Inaoka ${ }^{1)}$ and Naoko Morita ${ }^{1)}$
}

\begin{abstract}
The solitary fibrous tumor (SFT) is a rare neoplastic entity which typically originates from the pleura and other serosal tissues, and infrequently arises in the head and neck region. A 26 -year-old female, who complained of nasal obstruction, was referred to us for a tumor in the left nasal cavity. A contrast-enhanced computed tomography scan showed a heterogeneously enhanced mass. The pathological findings of this hemorrhagic tumor on the first biopsy were compatible with a nasal polyp; however, the specimen on rebiopsy revealed a spindle cell neoplasm which was immunohistologically positive for CD34 and bcl-2, leading to the diagnosis of SFT. The tumor was endoscopically resected, the pathologic finding of which was identical to the preoperative diagnosis. The patient showed no evidence of recurrence four years after the operation. Immunohistological staining is essential for the diagnosis of SFT, as HE staining alone is insufficient to differentiate it from other tumors.
\end{abstract}

Keywords : solitary fibrous tumor, head and neck region, nasal cavity, CD34, bcl-2

\section{References}

1) Ridder GJ, Kayser G, Teszler CB, et al. : Solitary fibrous tumors in the head and neck: new insights and implications for diagnosis and treatment. Ann Otol Rhinol Laryngol 116: 265270, 2007.

2) Tani A, Nomoto $Y$, Watanabe M, et al. : Two cases of solitary fibrous tumor. Pract Otol (Kyoto) 99: 239-245, 2006.

3) Klemperer $P$ and Rabin CB : Primary neoplasms of the pleura: a report of five cases. Arch Pathol 11: 385-412, 1931.

4) Janjua A, Sklar M, Macmillan C, et al. : Endoscopic resection of solitary fibrous tumors of the nose and paranasal sinuses. Skull Base 21: 129-134, 2011.

5) Alobid I, Alós L, Blanch JL, et al. : Solitary fibrous tumour of the nasal cavity and paranasal sinuses. Acta Otolaryngol 123: 71-74, 2003.

6) Kim TA, Brunberg JA, Pearson JP, et al. : Solitary fibrous tumor of the paranasal sinuses: CT and MR appearance. AJNR Am J Neuroradiol 17: 1767-1772, 1996.

7) Kawabata M, Matsune S and Kurono Y : A case report of a solitary fibrous tumor occurring in the paranasal sinus. Pract Otol (Kyoto) 100: 669-674, 2007.
8) Kobayashi Y, Liu A, Yamazaki M, et al. : Solitary fibrous tumor of the nasopharynx $-\mathrm{A}$ frequently recurrent and resected mesenchymal tumor of the maxillary sinases, nasal cavities and vesiblum and palate for 15 years - . Arch Histopathol Different Diagn 10: 9-12, 2003.

9) Hicks DL and Moe KS : Nasal solitary fibrous tumor arising from the anterior cranial fossa. Skull Base 14: 203-207, 2004.

10) Zeitler DM, Kanowitz SJ and Har-El G : Malignant solitary fibrous tumor of the nasal cavity. Skull Base 17: 239-246, 2007.

11) Furze AD, Peng $Y$ and Myers LL : Pathology case quiz 2. Solitary fibrous tumor of the nasal cavity and ethmoid sinus with intracranial extension. Arch Otolaryngol Head Neck Surg 134: 334, 336-337, 2008.

12) Takasaki K, Watanabe T, Hayashi $T$, et al. : Solitary fibrous tumor arising from the sphenoid sinus. Case Rep Med 2009: 316042, 2009.

13) Nai GA and Ramalho Neto GC : Solitary fibrous tumor of the nasal cavity. Braz J Otorhinolaryngol 75: 769, 2009.

14）安松隆治, 平川直也, 白土秀樹, 他：鼻腔内に生じた孤立 性線維性腫瘍の 1 例. 耳鼻と臨 55：74-78, 2009.
1) Department of Otolaryngology, Hyogo Prefectural Amagasaki Hospital

2) Fujiki E.N.T Clinic
Corresponding Author Address : Kayoko Hattori

k_hattori@ent.kuhp.kyoto-u.ac.jp 
15) Fujikura T, Ishida M, Sekine K, et al. : Solitary fibrous tumor arising from the superior nasal turbinate: a case report. J Nippon Med Sch 79: 373-376, 2012.

16) Bowe SN, Wakely PE Jr and Ozer E : Head and neck solitary fibrous tumors: diagnostic and therapeutic challenges. Laryngoscope 122: 1748-1755, 2012.

17) Guillou L, Fletcher JA, Fletcher CDM, et al. : Extrapleural solitary fibrous tumour and haemangiopericytoma. World Health Organization Classification of Tumours, Pathology and Genetics of Tumours of Soft Tissue and Bone (ed by Fletcher CDM, Unni KK and Mertens F). pp 86-90, IARC Press, Lyon, 2002.
18）神尾一樹，西井鉄平，荒井宏雅，他：16 年を経て肺転移を きたした腸間膜腫瘍の 1 例。日臨外会誌７3：1013-1016, 2012.

19) Robinson DR, Wu YM, Kalyana-Sundaram $\mathrm{S}$, et al. : Identification of recurrent NAB2-STAT6 gene fusions in solitary fibrous tumor by integrative sequencing. Nat Genet 45: 180-185, 2013.

20) Hasegawa T, Matsuno Y, Shimoda T, et al. : Extrathoracic solitary fibrous tumors: their histological variability and potentially aggressive behavior. Hum Pathol 30: 1464-1473, 1999.
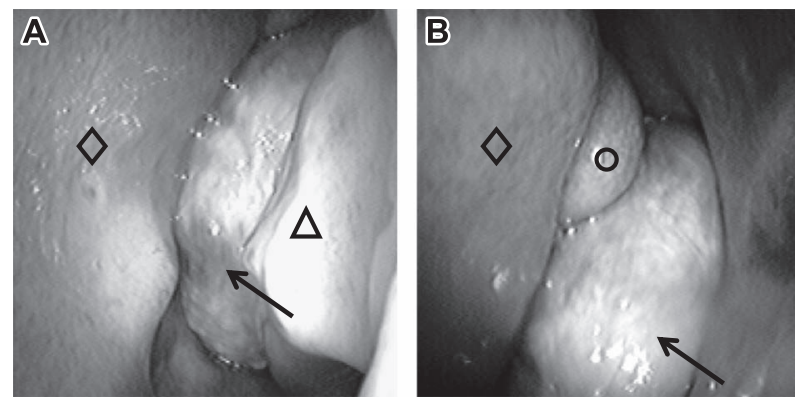

Endoscopic examination

A mass can be seen with a pale surface in the left nasal cavity. Arrows indicate the mass.

$\diamond$ : Nasal septum. $\triangle$ : Lower turbinate. $\bigcirc$ : Middle turbinate.
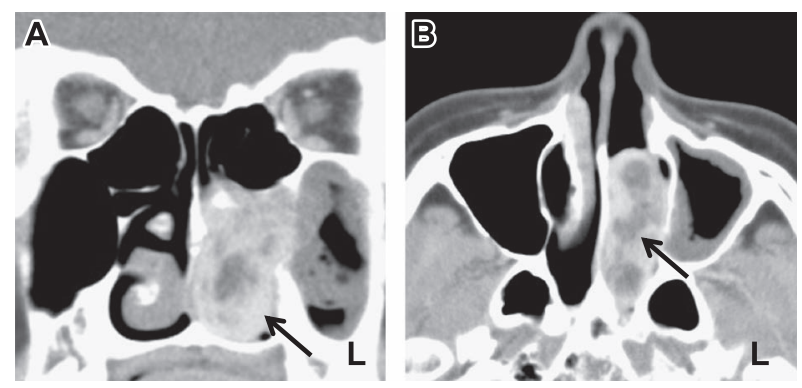

Contrast-enhanced computed tomography scan A heterogeneously enhanced mass can be observed. Arrows indicate the mass.
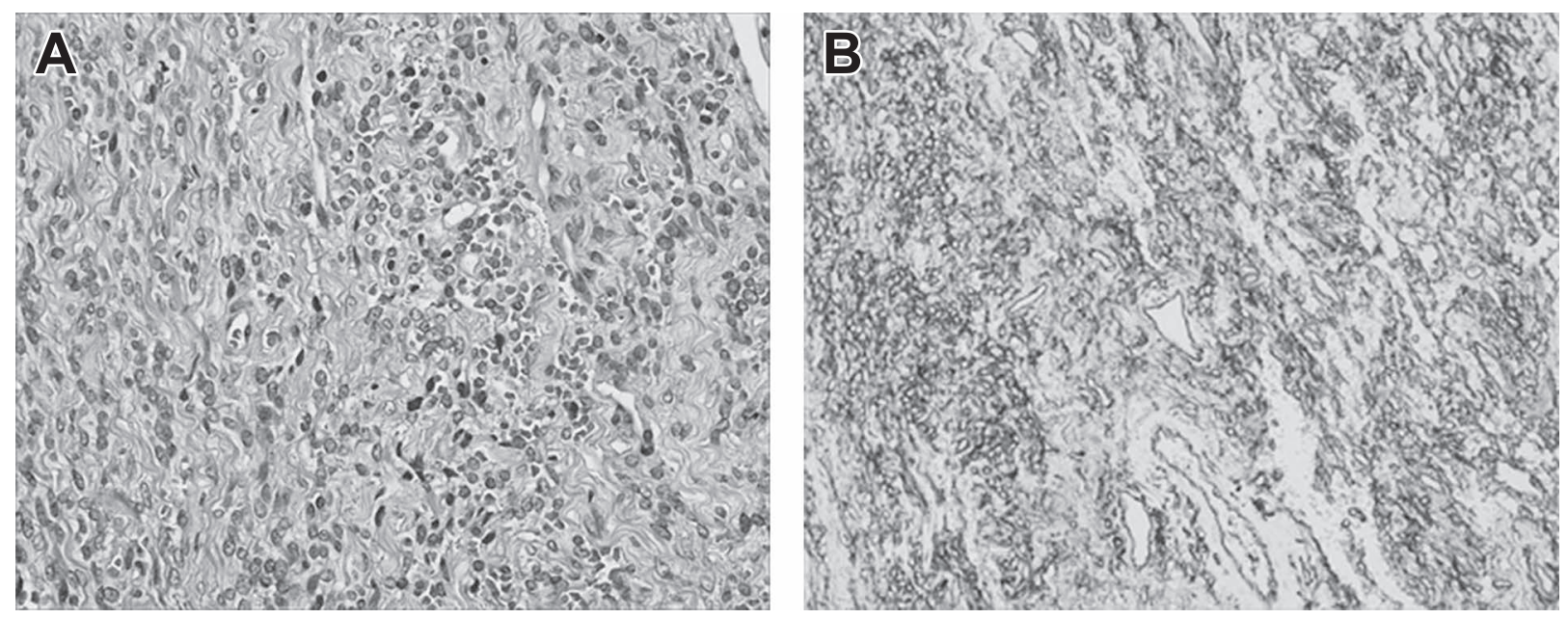

Staining of the tumor on the second biopsy

A: Hematoxylin and Eosin staining, $\times 400$.

B: CD34, $\times 400$. Positivity for CD34 is noted.

The histopathological findings were consistent with those of a solitary fibrous tumor. 